\title{
First record of Platypsyllus castoris Ritsema, 1869 (Coleoptera: Leiodidae) from Siberia
}

\author{
Alexey S. SAZHNEV ${ }^{1}$ and Fyodor A. BUDAEV ${ }^{2}$

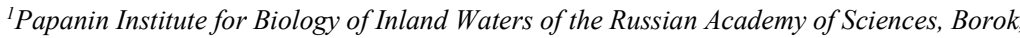 \\ 152742 Russia; e-mail: sazh@list.ru \\ ${ }^{2}$ Kemerovo State University, Krasnaya Str.6, Kemerovo650043 Russia; e-mail: budaevfedor95@mail.ru
}

\begin{abstract}
Holarctic species Platypsyllus castoris Ritsema, 1869 previously noted in Palaearctic only Europe and European part of Russia is found in Siberia (Russia, Altai Krai) for the first time. This species was collected on Eurasian beaver (Castor fiber Linnaeus, 1758).
\end{abstract}

Key words: beetles, Platypsyllinae, Russia, beaver, faunistic, new record

\section{INTRODUCTION}

Genus Platypsyllus Ritsema, 1869 (Leiodidae: Platypsyllinae) is represented by one Holarctic species - Platypsyllus castoris Ritsema, 1869. The beetles are ectoparasitic (as both adults and larvae) primary on the two species of beavers (Castor fiber Linnaeus, 1758 and C. canadensis Kuhl, 1820), less often of otters (Lontra canadensis (Schreber, 1777) and Lutra lutra (Linnaeus, 1758)), possibly other aquatic animals living near beaver lodges (Belfiore 2006, Peck 2006, Arzanov et al. 2013).

\section{MATERIAL AND METHODS}

The material has been collected by second author. All specimens were collected in a fur of hunted beavers (Castor fiber), and are stored in the Collection of aquatic invertebrates of the Papanin Institute for Biology of Inland Waters of the Russian Academy of Sciences (Yaroslavl Oblast, Borok, Russia, IBIW RAS) and F. Badaev personal collection (BPC).

Photography was taken using a stereomicroscope MC-5-ZOOM LED with ToupCam 10.0 MP CMOS camera. Photography enhanced by using Helicon Focus 7.6.4.

\section{RESULTS}

Family Leiodidae Fleming, 1821

Subfamily Platypsyllinae Ritsema, 1869

Genus Platypsyllus Ritsema, 1869

\section{Platypsyllus castoris Ritsema, 1869}

(Fig 1)

Material examined. Only adults: $1 \hat{\jmath}, 2+q$, Russia: Western Siberia, Altai Krai, Kytmanovsky Distr., env. Sosnovy Log vill., Kamenka River, on beaver, 23 Aug 2019, coll. F. Budaev, IBIW RAS; $2 \hat{\jmath} \hat{\jmath}, 5 ㅇ ㅜ$, same place, env. Staraya Taraba vill., Balakhcha River, on beaver, 27 July 2020, coll. F. Budaev, BPC. 


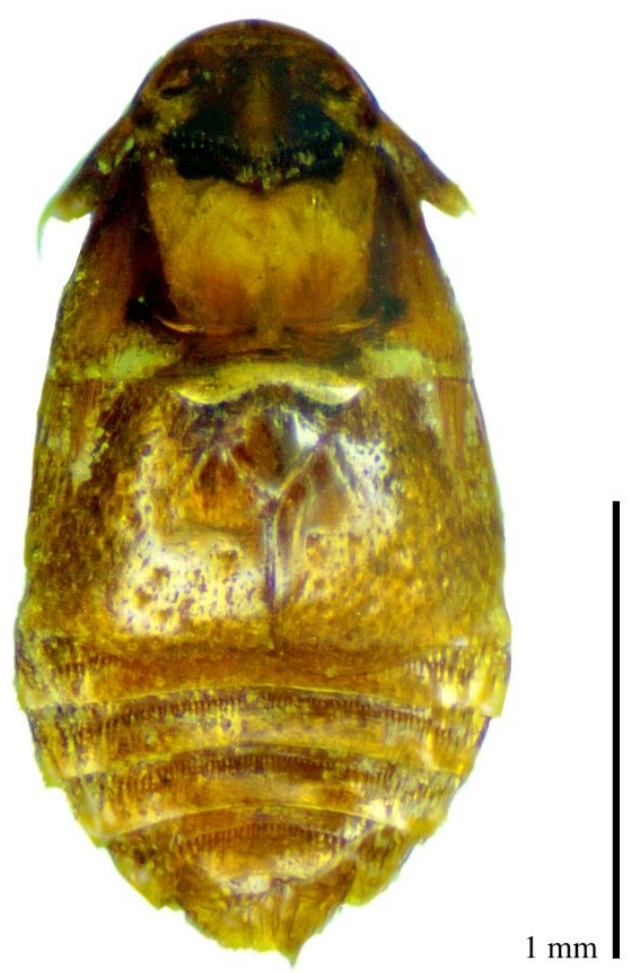

Fig. 1. Platypsyllus castoris Ritsema, 1869, male from Sosnovy Log vill, dorsal view. Photo by A. Sazhnev.

Distribution. The species have Holarctic distribution. In North America species know from Canada, United States (Peck, 2006), in Palaearctic Platypsyllus castoris recorded for Europe (Belgium, Belarus, The Czech Republic, France, Germany, Latvia, The Netherlands, Norway, Poland, Slovakia, Sweden and Switzerland) (Perreau 2015) and the European part of Russia, where the species is known from Voronezh (Prokin \& Kirejtshuk 2007), Rostov (Arzanov et al. 2013) and Saratov (Sazhnev et al. 2019) Oblasts.

\section{COMMENTS}

The species Platypsyllus castoris most likely dispersed between Eurasia and North America via the Bering land bridge together with the beaver (Repenning 1967). New records in the south of the European Russia and Siberia, may be indicate the restoration of the number and range of beavers and their ectoparasite such as Platypsyllus castoris. This species is expected to be found in Eastern Siberia and Russian Far East (including variant of invasion together with Castor canadensis).

\section{ACKNOWLEDGEMENTS}

The studies of the first author were carried out under the framework of the Russian state research project No. 121051100109-1. 


\section{REFERENCES}

Arzanov Yu.G., VAlov G.V. \& BAKhtadze G.B. 2013. Platypsyllus castoris Ritsema, 1869. (Coleoptera: Leiodidae) - new species from Rostov Region (Russia). Caucasian Entomological Bulletin 9 (1): 47-49. DOI: 10.23885/18143326-2013-9-1-47-49

BELFIORE N.M. 2006. Observation of a beaver beetle (Platypsyllus castoris Ritsema) on a North American river otter (Lontra canadensis Schreber) (Carnivora: Mustelidae: Lutrinae) in Sacramento County, California (Coleoptera: Leiodidae: Platypsyllinae). The Coleopterists Bulletin 60 (4): 312-313. DOI: 10.1649/0010065X(2006)60[312:OOABBP]2.0.CO;2

PECK ST.B. 2006. Distribution and biology of the ectoparasitic beaver beetle Platypsyllus castoris Ritsema in North America (Coleoptera: Leiodidae: Platypsyllinae). Insecta Mundi 20 (1-2): 85-94.

Perreau M. 2015. Family Leiodidae, pp. 180-291. In: LÖBL I. \& LöBL D. (eds.), Catalogue of Palaearctic Coleoptera. Vol. 2/1. Revised and updated version. Hydrophiloidea - Staphylinoidea. Leiden-Boston: Brill, 1702 pp.

Prokin A.A. \& KIREJTSHUK A.G. 2007. On Platypsyllus castoris Ristema, 1869 (Coleoptera, Leiodidae, Platypsyllinae) in Voronezh Province and notes on other leiodid beetles connected with mammals. Problems and perspectives of general entomology. Abstracts of the 13th Congress of Russian Entomological Society: 296-297.

REPENNING C.A. 1967. Palearctic-Nearctic mammalian dispersal in the late Cenozoic, pp. 288-311. In: HoPKINS D.A. (ed). The Bering land bridge. Stanford University Press, Palo Alto. CA, $512 \mathrm{pp}$.

SAZHNEV A.S., VolodChenKO A.N. \& ZABALUEV I.A. 2019. New data to the fauna of beetles (Coleoptera) of the Saratov Province. Report 2. Eversmannia 57: 9-1.

\section{STRESZCZENIE}

\section{[Pierwsze stwierdzenie Platypsyllus castoris Ritsema, 1869 (Coleoptera: Leiodidae) z Siberii]}

Holarktyczny gatunek Platypsyllus castoris Ritsema, 1869 - zewnętrzny pasożyt, żyjący głównie na futrze bobrów został znaleziony po raz pierwszy na Syberii (Rosja, Góry Ałtaju). Materiał został zebrany przez drugiego autora. Wszystkie okazy zostały zebrane z futra bobra europejskiego (Castor fiber). Nowe stwierdzenia z południa i europejskiej części Rosji oraz z Syberii mogą wskazywać na odnawianie się w liczbie i zasięgu bobra razem z jego ektoparazytem Platypsyllus castoris. Znalezienie tego gatunku jest spodziewane również we Wschodniej Syberii i na Dalekim Wschodzie Rosji. 